\section{Post discharge formula fortifi- cation of maternal human milk of very low birth weight preterm infants: an introduction of a feeding protocol in a University Hospital}

\author{
Abeer El Sakka,1,2 \\ Mohamed Sami El Shimi,1,2 \\ Kareem Salama, ${ }^{3}$ Hend Fayez ${ }^{1}$
}

1Neonatal Intensive Care; 2Department of Neonatology, Faculty of Medicine, Ain Shams University, Cairo, Egypt; ${ }^{3}$ Bachelor of Science Student, University of Texas, San Antonio, TX, USA

\section{Abstract}

The objective of this study is to determine the growth parameters and nutritional biochemical markers and complications of fortification of human milk by post discharge formula of preterm very low birth weight newborns (VLBW). Fifty preterm infants less than 37 weeks with weight less than $1500 \mathrm{~g}$ were enrolled in the study. They received parental nutrition and feeding according to our protocol. When enteral feeding reached $100 \mathrm{cc} / \mathrm{kg} /$ day, infants were randomized into two groups: group I, Cases, $n=25$, where post discharge formula (PDF) was used for fortification, group II, Controls, $n=25$ with no fortification. Infants of both groups were given $50 \%$ of required enteral feeding as premature formula. This protocol was used until infants' weight reached $1800 \mathrm{~g}$. Daily weight, weekly length and head circumference were recorded. Hemoglobin, albumin (Alb), electrolytes, blood urea nitrogen (BUN) and clinical complications were documented. Human milk fortification with PDF resulted in better growth with increase in weight 16.8 and $13.78 \mathrm{~g} / \mathrm{kg} /$ day $(\mathrm{P}=0.0430)$, length 0.76 and 0.58 $\mathrm{cm} /$ week $(\mathrm{P}=0.0027)$, and head circumference of 0.59 and $0.5 \mathrm{~cm} /$ week $(\mathrm{P}=0.0217)$ in cases and controls respectively. Duration of hospital stay was less in cases (22.76 versus 28.52 days in Controls), $\mathrm{P}=0.02$. No significant changes were found in serum electrolytes, BUN, or Alb between both groups. Hemoglobin was significantly higher in Cases, $\mathrm{P}=0.04$. There were no significant clinical complications. Our feeding protocol of fortification of human milk with PDF in preterm very low birth weight newborns resulted in better growth and decrease in length of hospital stay. The use of PDF could be an alternative option for fortification of mothers' milk for preterm VLBW infants in developing countries with low resources.

\section{Introduction}

Human milk from the preterm infant's mother is the preferred enteral feeding. Full enteral feeding is achieved earlier in preterm infants fed human milk compared with infant formula. Besides the nutritional value, immunologic and antimicrobial components in human milk promote infant's health and development. ${ }^{1}$ Among the reported benefits of human milk for preterm infants are the following: reduced infections, less necrotizing enterocolitis, and decreased feeding intolerance..$^{2,3}$ Obstacles of exclusive human milk feeding of preterm infants include; inadequate milk supply of the mother, volume restrictions, and limitations of intake of the infant. ${ }^{4}$

Biochemical analysis of milk from mothers of preterm infants especially during the first 2 weeks after delivery shows higher levels of energy and higher concentrations of fat, protein, and sodium but slightly lower concentration of lactose, calcium, and phosphorus compared with milk from mothers of term infant. ${ }^{2}$ A rapid rate of postnatal growth is essential to parallel the intrauterine rates. The protein content of milk from mothers of preterm infants is inadequate to meet the needs of most preterm infants especially by end of the first month. 5,6

Human milk fortifiers provide additional protein, minerals, and vitamins necessary for the optimal growth and development of the preterm infants. Adding these supplements to human milk in the first month postpartum, the resultant nutrient, mineral, and vitamin concentrations are similar to those formulas developed for feeding preterm infants. Fortification of milk from mothers of preterm infants might be used after discharge for very low birth weight (VLBW) infants if discharge happened before $1800 \mathrm{~g}$ to meet the growth needs of the preterm infant. ${ }^{7}$

The objective of this study was to determine if post discharge formula (PDF) is an alternative for fortification of preterm mothers' milk in underdeveloped countries where human milk fortifiers (HMF) are not available, and to detect possible complications.

\section{Materials and Methods}

This was a prospective case-control study. It was conducted at Ain Shams University Maternity Hospital Neonatal Intensive Care Unit (NICU) from November 2012 till April 2014. This study was approved by Pediatric Department Ethical Review Board. Our NICU is a level III care with the availability of Pediatric Sub-speciality consultation and Surgical Specialists. It is equipped to provide
Correspondence: Abeer El Sakka, Department of Neonatology, Faculty of Medicine, Ain Shams University, 38 Abbassia, Cairo 15566, Egypt.

Tel.: +20.830 .7659766 .

E-mail: drasakka@gmail.com

Key words: Breastfeeding; fortification; growth; preterm; hospital stay.

Contributions: AES, research idea, design, analysis, revising, drafting and final approval of the work, agreement that all the work is appropriately done; MSES, design, revision, final approval, agreement that the work was appropriately investigated; KS, design of the study, drafting, analysis, revision, final approval, agreement that the work was appropriately investigated; $\mathrm{HF}$, data collection, interpretation of the work, revising, final approval, agreement that the work was appropriately investigated.

Conference presentation: abstract of this research has been presented at "Pediatric Nutrition Conference" in New Orleans, USA, August 2016.

Funding: the authors funded this research by their personal funds.

Conflict of interest: the authors declare no poten tial conflict of interest.

Received for publication: 1 June 2016.

Revision received: 1 July 2016.

Accepted for publication: 9 July 2016.

This work is licensed under a Creative Commons Attribution NonCommercial 4.0 License (CC BYNC 4.0).

(C) Copyright A. El Sakka et al., 2016

Licensee PAGEPress, Italy

Pediatric Reports 2016; 8:6632

doi:10.4081/pr.2016.6632

assisted ventilation from minimal up to conventional and high frequency ventilation.

Inclusion criteria were preterm (gestational age $<37$ weeks), and very low birth weight (birth weight $<1500 \mathrm{~g}$ ) infants, no intolerance to enteral feedings, enteral feeding volume of $100 \mathrm{~mL} / \mathrm{kg} /$ day, and mothers willing to provide breast milk by manual breast bump.

Infants born with congenital abnormalities, had intolerance to enteral feedings, or any medical condition as hyperbilirubinemia requiring phototherapy, hypoglycemia, hyponatremia or respiratory illness necessitating any kind of assisted ventilation or their mothers had contraindication to breastfeeding were not eligible for our study (Figure 1).

An informed consent was obtained from parents to enroll their infant in the study. Perinatal history was taken and clinical examination was performed for all newborn infants. 
Daily weight, weekly length and frontal-occipital circumference were measured. Laboratory results were reviewed especially hemoglobin level (Hb), hematocrit, albumin (Alb), blood urea nitrogen (BUN), and electrolytes as sodium $(\mathrm{Na})$, potassium $(\mathrm{K})$, calcium $(\mathrm{Ca})$ and phosphorus (P). Certified Breastfeeding consultants provided counseling for breast milk expression, storage, and transport to the NICU.

We applied the following protocol:8-11 parenteral nutrition was initiated as soon as possible on the day of delivery with glucose $5 \%$ at a rate of $3.5 \mathrm{~g} / \mathrm{kg} / \mathrm{min}$ and was advanced by $1-2$ $\mathrm{g} / \mathrm{kg} / \mathrm{min} /$ day until maximum of $12 \mathrm{~g} / \mathrm{kg} / \mathrm{min}$. Amino acids were started as $3.5 \mathrm{~g} / \mathrm{kg} /$ day and increased to $4 \mathrm{~g} / \mathrm{kg} /$ day. Calcium $650 \mathrm{mg} / \mathrm{dL}$, multivitamins, zinc and selenium were added.

Intra-lipid was given through separate line as $1 \mathrm{~g} / \mathrm{kg} /$ day and increased to $2-3 \mathrm{~g} / \mathrm{kg} /$ day. Enteral feeding was started in the first 2 days after birth. Priming the gastrointestinal tract
(GI) was done by unfortified maternal breast milk 10-20 mL/kg/day. After few days of priming the GI, feeding was advanced by $10-20$ $\mathrm{mL} / \mathrm{kg} /$ day. Total parental nutrition (TPN) was reduced accordingly to give the desired daily fluid intake. TPN was stopped when enteral feeding reached $120 \mathrm{~mL} / \mathrm{kg} /$ day. Full enteral intake of $150-\mathrm{mL} / \mathrm{kg} /$ day was aimed to be reached by day 10 of life.

Mothers used manual breast pumps for breast milk expression as they were the only breast pumps available in Egypt. Although breastfeeding consultation was offered to mothers by certified breastfeeding consultant, yet the amount of expressed breast milk covered only about $50 \%$ of enteral needs/day and exclusive breastfeeding was not possible. So we gave $50 \%$ of the total enteral milk volume by premature formula (PMF). The available premature formula was Babelac Premature 24 cal/fl oz by Danone Baby Nutrition, while the post discharge formula (PDF) was Similac Neosure, by Abbott Laboratories.

Infants who tolerated $100 \mathrm{~mL} / \mathrm{kg} /$ day enteral feeding were randomly categorized into two groups; Group I, (intervention group or PDF fortified human milk group) $\mathrm{PDF}+$ Bebelac Premature formula, and group II (Controls or non intervention group) with no fortification of breast milk+Babelac Premature formula. Fortification was started with $22 \mathrm{cal} / \mathrm{fl}$ oz for 2 to 4 days then $24 \mathrm{cal} / \mathrm{fl} \mathrm{oz}$, if tolerated $27 \mathrm{cal} / \mathrm{fl}$ oz was used till the infant reached $1800 \mathrm{~g}$, which was set as discharge weight in our unit. Supplementation of vitamin D with start of enteral feeding while iron was prescribed when enteral feeding reached $150 \mathrm{cc} / \mathrm{kg} /$ day.

According to manufacture's guidelines of PDF; 1 tsp level powder +130 mL Term Human milk gives 22 calories, 1 tsp level powder +70 mL Term Human milk gives 24 calories while 1 tsp level powder $+40 \mathrm{~mL}$ Term Human milk

Table 1. Nutritional components in term human milk fortified by post discharge formula and in Bebelac Premature Formula.

\begin{tabular}{|c|c|c|c|c|}
\hline Nutrient per $100 \mathrm{~mL}$ & 22 Cal/fl oz & $\begin{array}{l}\text { in milk+Simil } \\
24 \mathrm{Cal} / \mathrm{fl} \mathrm{oz}\end{array}$ & $\begin{array}{l}\text { ure } \\
27 \mathrm{Cal} / \mathrm{fl} \mathrm{oz}\end{array}$ & $\begin{array}{c}\text { Bebelac premature } \\
24 \mathrm{Cal} / 30 \mathrm{~mL}\end{array}$ \\
\hline Energy, Cal & 76 & 83 & 93 & 80 \\
\hline Protein, $g$ & 1.27 & 1.45 & 1.73 & 2.4 \\
\hline Fat, g & 4.33 & 4.7 & 5.27 & 4.4 \\
\hline $\mathrm{CHO}, \mathrm{g}$ & 8.01 & 8.69 & 9.77 & 7.8 \\
\hline Calcium, mg & 37 & 44 & 56 & 100 \\
\hline Phosphorus, mg & 19 & 24 & 31 & 50 \\
\hline Magnesium, mg & 4.2 & 4.9 & 5.9 & 10 \\
\hline Iron, mg & 0.19 & 0.32 & 0.53 & 0.9 \\
\hline Zinc, mg & 0.22 & 0.31 & 0.45 & 0.7 \\
\hline Manganese, mcg & 1 & 2 & 3 & 10 \\
\hline Copper, mcg & 35 & 44 & 57 & 80 \\
\hline Iodine, mcg & 12 & 13 & 15 & 25 \\
\hline Selenium, mcg & 1.7 & 1.8 & 2.1 & 1.9 \\
\hline Sodium, mg & 21 & 23 & 26 & 32 \\
\hline Potassium, mg & 65 & 74 & 90 & 75 \\
\hline Chloride, mg & 48 & 53 & 61 & 61 \\
\hline Vitamin A, IU & 263 & 294 & 344 & 733.3 \\
\hline Vitamin D, IU & 8 & 13 & 21 & 200 \\
\hline Vitamin E, IU & 0.7 & 1 & 1.4 & 3.3 \\
\hline Vitamin K, mcg & 1.2 & 2 & 3.3 & 6.6 \\
\hline Thiamine B1, mcg & 40 & 56 & 81 & 140 \\
\hline Riboflavin B2, mcg & 48 & 58 & 75 & 200 \\
\hline Vitamin B6, mcg & 29 & 36 & 47 & 120 \\
\hline Vitamin B12, mcg & 0.08 & 0.11 & 0.16 & 0.2 \\
\hline Niacin, mcg & 320 & 461 & 685 & 3000 \\
\hline Folic acid, mcg & 7.1 & 8.9 & 11.7 & 48 \\
\hline Pantothenic acid, mcg & 248 & 305 & 395 & 1000 \\
\hline Biotin, mcg & 1.2 & 1.8 & 2.9 & 3 \\
\hline Vitamin C, mg & 5 & 6 & 8 & 16 \\
\hline Choline, mg & 10 & 12 & 13 & 10 \\
\hline Inositol, mg & 18 & 20 & 24 & 30 \\
\hline
\end{tabular}


gives 27 calories. ${ }^{12}$ But we used mothers' preterm human milk instead of term human milk. We depended on clinical criteria to assess feeding intolerance as overall clinical status, abdominal examination, emesis, and characteristics of gastric residue, or any change in stools frequency. Further investigations were available if necrotizing enterocolitis was suspected. ${ }^{13}$ A Feeding Tolerance Algorithm was followed for assessing feeding intolerance. Gastric residual volume (GRV) was checked every 3 hours for infants receiving $>40 \mathrm{~mL} / \mathrm{kg}$ of enteral feedings. If GRV was $>50 \%$ or there was marked and persistent increase from usual residual, abdominal distension or baby appeared sick, further evaluation was done including abdominal $\mathrm{x}$ ray, sepsis work up as complete blood count (CBC), and C-reactive protein. Newborns with normal physical exams and minimal symptoms were refeed but at half the previous tolerated volume and were serially evaluated. While those with abnormal exam were put on nil per $o s$ and treated according to necrotizing enterocolitis protocol. Infants who had feeding intolerance and enteral feeding could not advanced were excluded from the study. Manufactures' description of nutritional components of human milk fortified by PDF, and PMF are included in Table 1.

\section{Statistical methods}

We used SPSS version 24 for statistics. For continuous data, mean \pm SD and Student's t-test were used. Non-parametric Mann Whitney U test was used where appropriate if data were not normally distributed. While percent (\%) and Chi Square test were used for categorical variables. Pearson test was used when appropriate. A P-value of $<0.05$ was considered statistically significant.

\section{Results}

Fifty low birth weight preterm infants completed the study. Group I (Cases, $n=25$ ) where PDF was used for fortification of mothers' breast milk, and group II (Controls, $\mathrm{n}=25$ ) where no fortification was added. At the beginning of the study, there was no significant difference between the two groups as regards gestational age, gender, birth weight, length and occipital-frontal circumference, $\mathrm{P}>0.05$. The main causes of prematurity in both groups were maternal pre-eclampsia, multiple gestation, antepartum and accidental hemorrhage.

\section{Growth parameters}

Significant difference in gain of weight, length and head circumference was found in intervention group compared with Controls, $\mathrm{P}<0.05$ (Table 2).

\section{Nutritional variables}

There was no statistical difference between Cases and Controls in days of only TPN, mixed feeding (TPN+enteral feeding), only enteral feeding, or age at enteral intake of 100 $\mathrm{mL} / \mathrm{kg} /$ day, $\mathrm{P}>0.05$ (Table 3). Infants in the intervention group stayed in the hospital less than the Control group, 22.76 versus 28.52 days, $\mathrm{P}=0.02$ (Figure 2).

Although feeding intolerance was more in Cases ( $n=3)$ compared with Controls $(n=1)$, this was not statistically significant, $P>0.05$. Other complications as sepsis and reflux were

Table 2. Infants characteristics.

\begin{tabular}{|c|c|c|c|}
\hline Newborn characteristics & PDF $(n=25)$, mean \pm SD or $\%$ & NO Fortification $(\mathrm{n}=25)$, mean \pm SD or $\%$ & P value \\
\hline $\begin{array}{l}\text { Sex } \\
\quad \text { Males } \\
\quad \text { Females }\end{array}$ & $\begin{array}{l}14(56 \%) \\
11(44 \%)\end{array}$ & $\begin{array}{l}14(56 \%) \\
11(44 \%)\end{array}$ & 1.00 \\
\hline Birth weight, g & $1291.8 \pm 105.3$ & $1290.3 \pm 177.4$ & 0.97 \\
\hline Gestational age, weeks & $32.08 \pm 2.53$ & $31.37 \pm 2.62$ & 0.33 \\
\hline $\begin{array}{l}\text { Mode of delivery } \\
\text { SVD } \\
\text { CS }\end{array}$ & $\begin{array}{c}4(16 \%) \\
21(84 \%)\end{array}$ & $\begin{array}{c}5(20) \\
20(80)\end{array}$ & 0.71 \\
\hline Apgar score at 1 minute & $6.24 \pm 1.2$ & $6.28 \pm 106$ & 0.90 \\
\hline Apgar score at 5 minutes & $7.88 \pm 0.93$ & $8.32 \pm 0.95$ & 0.10 \\
\hline
\end{tabular}

Table 3. Clinical and nutritional variables.

\begin{tabular}{|c|c|c|c|}
\hline Study variable & PDF fortification & No fortification & P value \\
\hline Weight gain, gm/kg/d & $16.8 \pm 5.5$ & $13.8 \pm 4.7$ & 0.04 \\
\hline Length gain, cm & $0.76 \pm 0.2$ & $0.58 \pm 0.19$ & 0.003 \\
\hline OFC gain, cm & $0.59 \pm 0.16$ & $0.49 \pm 0.11$ & 0.02 \\
\hline TPN only, days & $0.48 \pm 1.23$ & $0.2 \pm 0.65$ & 0.33 \\
\hline Mixed feeding (TPN+enteral), days & $10.20 \pm 7.32$ & $7.76 \pm 4.89$ & 0.17 \\
\hline Enteral feeding duration, days & $22.4 \pm 11.50$ & $20.32 \pm 32$ & 0.45 \\
\hline Age at enteral intake of $100 \mathrm{~mL} / \mathrm{kg} /$ day & $8.24 \pm 3.5$ & $10.24 \pm 4.9$ & 0.10 \\
\hline Age at full enteral intake $(160 \mathrm{~mL} / \mathrm{kg})$ & $11.12 \pm 3.59$ & $14.44 \pm 7$ & 0.04 \\
\hline $\begin{array}{l}\text { Complications } \\
\text { Feeding intolerance } \\
\text { Reflux } \\
\text { Sepsis } \\
\text { No complications }\end{array}$ & $\begin{array}{c}3(12 \%) \\
0(0 \%) \\
1(4 \%) \\
21(84 \%)\end{array}$ & $\begin{array}{c}1(4 \%) \\
4(16 \%) \\
0(0 \%) \\
20(80 \%)\end{array}$ & 0.11 \\
\hline Length of hospital stay, days & $22.76 \pm 8.8$ & $28.52 \pm 7.9$ & 0.02 \\
\hline
\end{tabular}

PDF, post discharge formula; OFC, occipito-frontal circumference; TPN, total parenteral nutrition. 
not statistically significant between the two groups. Infants who developed complications were excluded from the study.

\section{Biochemical variables}

We did not find statistical significance between serum Ca, P, Alb, BUN and Hematocrit, $\mathrm{P}>0.05$. While $\mathrm{Hb}$ was statistically higher in Cases than Controls, $\mathrm{P}=0.03$ (Table 4). These biochemical parameters were compared at the beginning of the study and at discharge. As most infants were healthy preterm VLBW, frequent checking of these parameters was not a routine in our NICU.

\section{Discussion}

American Academy of Pediatrics recommends human milk for all preterm infants because of its proven both short and long term benefits. ${ }^{14}$ Yet human milk requires nutrient fortification to meet the protein and mineral needs of the rapidly growing preterm infant. Commercial human milk fortifiers are available in developed countries of either bovine or human milk. ${ }^{15}$ None of these milk fortifiers is available in Egypt while post-discharge formula is affordable and easy to obtain.

To our knowledge this is the first study, which compared fortification of mothers' milk of preterm VLBW infants with no fortification group. In the present study fortification of breast milk by PDF resulted in better growth in Cases with more increase in weight, length and head circumference, $\mathrm{P}<0.5$. We found that cases had younger age at full intake than controls $(160 \mathrm{cc} / \mathrm{kg} /$ day $)$ with significant difference $(\mathrm{P}=0.04)$. In the current study we reported shorter hospital stay, $\mathrm{P}=0.02$.

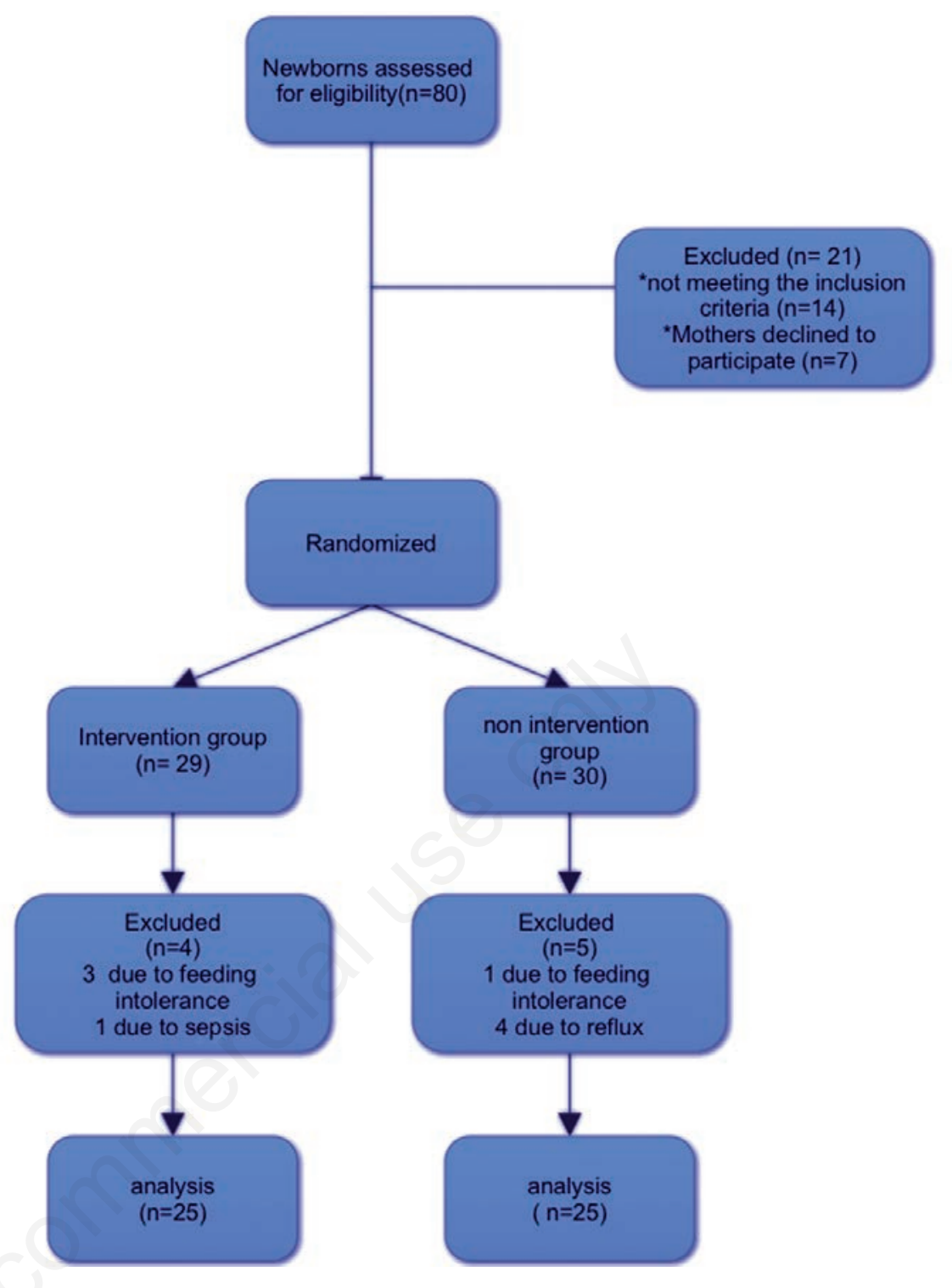

Figure 1. Patient eligibility flow diagram.

Table 4. Biochemical variables.

\begin{tabular}{|c|c|c|c|}
\hline Biochemical variable & PDF fortification, mean \pm SD & No fortification, mean \pm SD & P value \\
\hline $\begin{array}{l}\text { Serum calcium, mg/dL } \\
\text { At beginning of study } \\
\text { At discharge }\end{array}$ & $\begin{array}{c}9.24 \pm 1.1 \\
9.58 \pm 0.67\end{array}$ & $\begin{array}{l}9.42 \pm 1.07 \\
9.69 \pm 1.12\end{array}$ & $\begin{array}{l}0.54 \\
0.67\end{array}$ \\
\hline $\begin{array}{l}\text { Serum phosphorus, } \mathrm{mg} / \mathrm{dL} \\
\text { At beginning of study } \\
\text { At discharge }\end{array}$ & $\begin{array}{l}4.8 \pm 0.993 \\
4.36 \pm 1.05\end{array}$ & $\begin{array}{c}4.36 \pm 0.93 \\
4.4 \pm 1.47\end{array}$ & $\begin{array}{l}0.10 \\
0.59\end{array}$ \\
\hline $\begin{array}{l}\text { Serum albumin, g/dL } \\
\text { At beginning of study } \\
\text { At discharge }\end{array}$ & $\begin{array}{c}2.8 \pm 0.33 \\
2.95 \pm 0.32\end{array}$ & $\begin{array}{c}2.9 \pm 0.54 \\
3.06 \pm 0.32\end{array}$ & $\begin{array}{l}0.24 \\
0.30\end{array}$ \\
\hline $\begin{array}{l}\text { Serum blood urea nitrogen } \\
\text { At beginning of study } \\
\text { At discharge }\end{array}$ & $\begin{array}{l}10.20 \pm 6.73 \\
14.80 \pm 4.76\end{array}$ & $\begin{array}{c}12.2 \pm 5.3 \\
16.36 \pm 8.76\end{array}$ & $\begin{array}{l}0.14 \\
0.44 \\
\end{array}$ \\
\hline $\begin{array}{l}\text { Hemoglobin, } \mathrm{g} / \mathrm{dL} \\
\text { At beginning of study } \\
\text { At discharge }\end{array}$ & $\begin{array}{l}17.35 \pm 2.08 \\
11.94 \pm 2.32\end{array}$ & $\begin{array}{c}17.75 \pm 75 \\
10.75 \pm 1.47\end{array}$ & $\begin{array}{l}0.51 \\
0.04\end{array}$ \\
\hline $\begin{array}{l}\text { Hematocrit, } \mathrm{g} / \mathrm{dL} \\
\text { At beginning of study } \\
\text { At discharge }\end{array}$ & $\begin{array}{c}47.63 \pm 5.22 \\
34.11 \pm 6.6\end{array}$ & $\begin{array}{l}48.74 \pm 5.79 \\
30.95 \pm 4.59\end{array}$ & $\begin{array}{l}0.48 \\
0.051\end{array}$ \\
\hline
\end{tabular}


There is only one recent study from Thailand which used PDF for very low birth weight preterm infants. ${ }^{16}$ But that study compared fortification of human milk with either PDF or HMF. They did not find any significant difference in growth parameters, age at full enteral feeding or length of hospital stay between the intervention group and the control group. This might be explained by noting that our control group did not receive any kind of fortification while in their study they used HMF for the control group.

Earlier research studied HMF but non of them introduced PDF, probably because all of them were done in developed countries where HMF are easy to obtain. Martins and Krebs'17 found that HMF resulted in better growth in intervention group. They found more increase in weight, length and head circumference, $\mathrm{P}=0.075,0.003$, and 0.0001 respectively. Di Natale and colleagues ${ }^{18}$ demonstrated that the use of fortified human milk produces adequate growth in premature infants and satisfies the specific nutritional requirements of these infants. Martin and Kreb17 showed that the length of hospital stay in the intervention group was longer than the control group until reaching $1800 \mathrm{~g}$. They explained it by the lower mean weight of the intervention group at the beginning of their study. However, this did not show statistical difference. They also had shorter duration of hospital stay in intervention than control group but that was not statistically significant

In this study, we measured serum electrolytes ( $\mathrm{Na}, \mathrm{K}, \mathrm{Ca}$, and $\mathrm{P})$ at admission and discharge in both groups. We found that there was no significant difference between the two groups. Heiman and Schanler ${ }^{19}$ showed that infants fed unfortified human milk had progressive decreases in serum phosphorus and increases in serum calcium. But Lucas and colleagues ${ }^{20}$ found that there was no significant difference in plasma phosphorus between groups at any age. Those studies had used HMF for fortification of human milk while we used PDF.

In the current study hemoglobin and hematocrit were significantly lower in controls. This might be explained by the fact that Cases had additives of nutrients as iron while Controls did not. Iron supplementation was given to infants when they reached full intake of $\mathbf{1 5 0}$ $\mathrm{mL} / \mathrm{kg} /$ day in either group. While our study did not show any significant difference in Alb or BUN between groups, Heiman and Schanler ${ }^{19}$ showed that indices of protein nutritional status, e.g. BUN, serum Alb and total protein were lower in interventional group. The difference between our results and their study might be because they used different human milk fortifier. In this research only 3 cases (12\%) had feeding intolerance and one (4\%) had sepsis. None of the newborns in interventional group had reflux. In the control group only one newborn (4\%) had feeding intolerance while four (16\%) had reflux, $(\mathrm{P}=0.1)$. There was no statistical significance between these clinical complications. Khorona and colleagues ${ }^{16}$ did not report significant difference between interventional group where PDF was used and control group with HMF use.

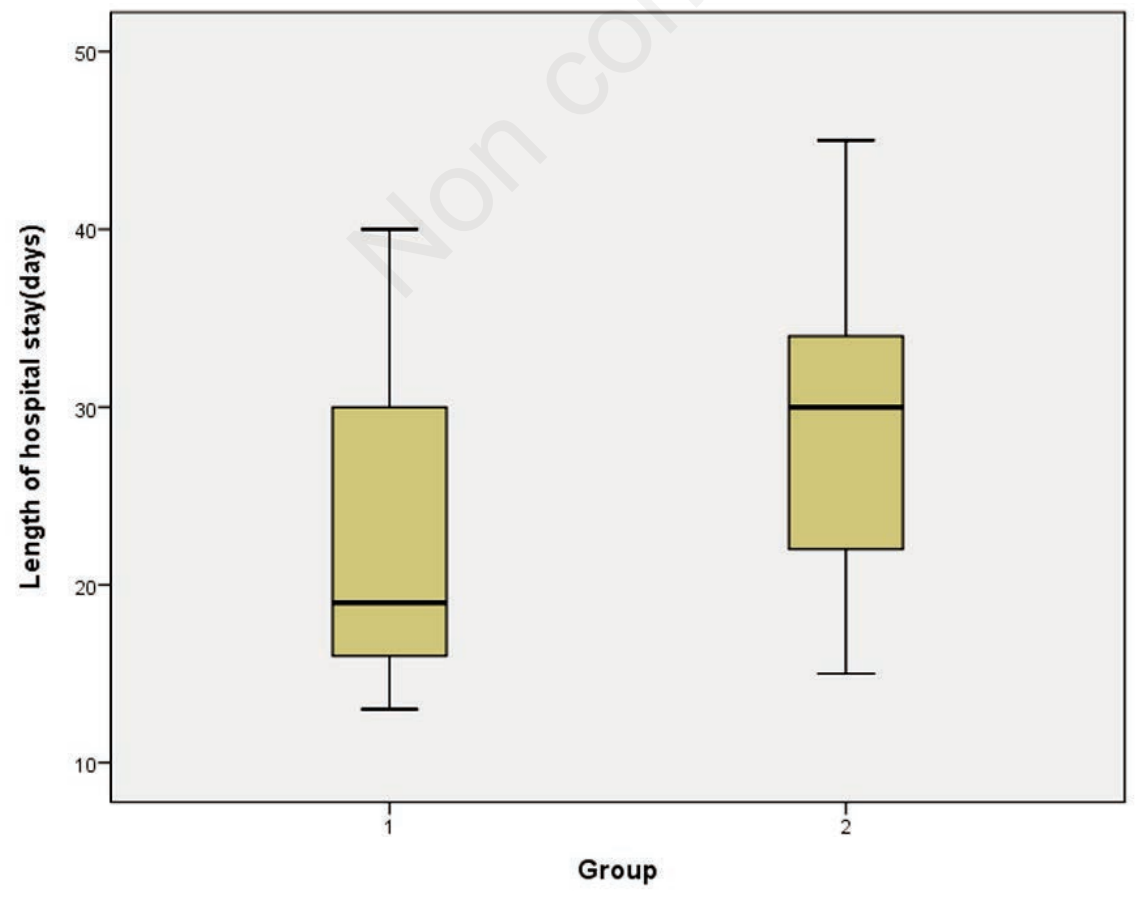

Figure 2. Length of hospital stay in cases (1) and control (2) groups.
Although powdered human milk fortifiers are not sterile and there is concern about contamination with gram negative bacteria (Coronobacter sakazakii), we had not recorded any related infection in infants who were fed PDF.21,22 Individualized human milk fortification, which is based on analysis of maternal milk had been described by Reali and colleagues. ${ }^{23}$ It showed better growth outcomes, but it is expensive and necessitates analysis of milk samples.

The mother of preterm infant requires education, equipment, and encouragement to successfully initiate and sustain lactation. One of the limitations in this study was inadequate breast milk provided by the mothers. We had to use $50 \%$ only of the infant's enteral intake as PDF fortified breast milk. Pharmacological galactagogues as domepridone to augment milk production were not prescribed, but we advised mothers to use natural galactagogues as dates and Fenugreek. ${ }^{24}$ Donor breast milk is not an option in Egypt as breast milk banks are not permitted.

Further studies are required to investigate the causes of insufficient breast milk in mothers of preterm infants. NICUs with accommodation for preterm mothers might help them provide more breast milk. Other studies, which would include mothers with only good breast milk supply for exclusive enteral feeding with fortification, might endorse our results and detect more complications of use of PDF in this vulnerable group of infants.

\section{Conclusions}

Breast milk fortification with PDF resulted in significant growth increase without significant complications. Widespread application in our NICUs might lead to shorter duration of NICU admission thus decreasing the cost and complications associated with prolonged NICU stay.

\section{References}

1. Schanler RJ, Lau C, Hurst NM, Smith EO. Randomized trial of donor human milk versus preterm formula as substitutes for mothers' own milk in the feeding of extremely premature infants. Pediatrics 2005;116:400-6.

2. Atkinson SA. Effects of gestational age at delivery on human milk components. In: Jensen RG, ed. Handbook of milk composition. San Diego: Academic Press; 1995. pp 225-37.

3. Lucas A, Cole TJ. Breast milk and neonatal necrotizing enterocolitis. Lancet 1990;336: 1519-23. 
4. Schanler RJ, Krebs NF, Mass SB, et al. Chapter 14: Breastfeeding and human milk for preterm infants. In: Breast feeding handbook for physicians. 2nd ed. Elk Grove Village, IL American College of Obstetric and Gynecology and American Academy of Pediatrics; 2014. pp 217-31.

5. Butte NF, Garza C, Johnson CA, et al. Longitudinal changes in milk composition of mothers delivering preterm and term infants. Early Hum Dev 1984;9:153-62.

6. Lucas A, Hudson GJ. Preterm milk as a source of protein for low birthweight infants. Arch Dis Child 1984;59:831-6.

7. Kleinman RE, Greer FR. Chapter 5: nutritional needs of preterm infant. In: Pediatric Nutrition. American Academy of Pediatrics Committee on Nutrition. 7th ed. Elk Grove Village, IL: American Academy of Pediatrics; 2014. pp 11-150.

8. Abrams SA, Adams JM, Anderson DM et al. Guidelines for acute care of the neonate. 23rd ed. Baylor College of Medicine, Department of Pediatrics, Section of Neonatology: Houston, Texas; 2015-2016. pp 143-60.

9. Hurst N. Breastfeeding. In: Clotherty JP, Eichenwald EC, Hansen AR, Stark AR, eds. Manual of Neonatal Care. $7^{\text {th }}$ ed. Lippinctt Williams \&Wilkins: Philadelphia, PA, USA; 2012. pp 263-8.

10. Schanler RJ, Abrams SA, Hoppin AG. Parenteral nutrition in premature infants. Available from: http://www.uptodate.com/ contents/parenteral-nutrition-in-prema- ture-infants? source $=$ search_result \& search $=$ Parenteral+nutrition + in + premature+infants\&selectedTitle $=1 \% 7 \mathrm{E} 150$

11. Groh-Wargo S, Sapsford A. Enteral nutrition support of the preterm infant in the neonatal intensive care unit. Nutr Clin Pract 2009;24:363-76.

12. Neofax . A manual of drugs used in neonatal care. Thomson Reuters: New York, NY, USA; 2011. p 381.

13. Young C, Sharma R, Handfield M, et al. Biomarkers for infants at risk for necrotizing enterocolitis: clues to prevention? Pediatr Res 2009;65:91R-97R.

14. Section on Breastfeeding, Johnston M, Landers S, et al. Breastfeeding and the use of human milk. Pediatrics 2012;129: e827-41.

15. Schanler RJ, Abrams SA, Kim MS. Human milk feeding and fortification of human milk for premature infants. Available from: http://www.uptodate.com/contents/humanmilk-feeding-and-fortification-of-humanmilk-for-premature-infants? source $=$ search_result\&search=Human+milk+fee ding+and+fortification+of+human+milk + for+premature+infants.\&selectedTitle $=$ 1\%7E150

16. Khorana M, Jiamsajjamongkhon C. Pilot study on growth parameters and nutritional biochemical markers in very low birth weight preterm infants fed human milk fortified with either human milk fortifier or post discharge formula. J Med Assoc Thai 2014;97:S164-75.
17. Martins EC, Krebs VL. Effects of the use of fortified raw maternal milk on very low birth weight infants. J Pediatr (Rio J) 2009;85:157-62. [Article in English, Portuguese ]

18. Di Natale C, Coclite E, Di Ventura L, Di Fabio S. Fortification of maternal milk for preterm infants. J Matern Fetal Neonatal Med 2011;24:41-3.

19. Heiman H, Schanler RJ. Enteral nutrition for premature infants: the role of human milk. Semin Fetal Neonatal Med 2007; 12:26-34.

20. Lucas A, Fewtrell MS, Moreley R, et al. Randomized outcome trial of human milk fortification and developmental outcome in preterm infants. Am J Clin Nutr 1996; 64:142-51.

21. Robbins ST, Beker LT. Infant feedings: guidelines for preparation of formula and breast-milk in health care facilities. American Dietetic Association, 2004.

22. Center for Disease Control and Prevention. Enterobacter Sakazakii infections associated with the use of powdered infant formula. Tennessee, 2001.

23. Reali A1, Greco F, Fanaro S, et al. Fortification of maternal milk for very low birth weight (VLBW) pre-term neonates. Early Hum Dev 2010;86:33-6.

24. El Sakka A, Salama MA, Salama K. The effect of fenugreek herbal tea and palm dates on breast milk production and infant weight. J Pediatr Sci 2014;6:e202. 